\title{
TRICHINELLA INFECTION OF WILD CARNIVORANS IN PRIMORSKY KRAI, RUSSIAN FAR EAST
}

\author{
Ivan V. Seryodkin ${ }^{1}$, Irina M. Odoyevskaya ${ }^{2}$, Sergey V. Konyaev ${ }^{3}$, Sergey E. Spiridonov $^{4}$ \\ ${ }^{1}$ Pacific Geographical Institute FEB RAS, Russia \\ e-mail:seryodkinivan@inbox.ru \\ ${ }^{2}$ K.I. Skryabin and Y.R. Kovalenko All-Russian Scientific Research Institute \\ of Experimental Veterinary Medicine of RAS, Russia \\ ${ }^{3}$ Institute of Systematics and Ecology of Animals SB RAS, Russia \\ ${ }^{4} A$.N. Severtsov Institute of Ecology of RAS, Russia
}

Received: 03.05.2020. Revised: 13.06.2020. Accepted: 17.06.2020.

\begin{abstract}
Nematodes of the genus Trichinella cause trichinosis, which is a zoonotic disease of humans, wild and domestic animals. In the Russian Far East, trichinosis has a natural focal character. Carnivorans (Carnivora), living in natural ecosystems including Protected Areas, are the main hosts of Trichinella. The peculiarities of Trichinella circulation in natural environment and the parasite prevalence in wild animals of different species remain poorly understood as well as the species composition of the Trichinella genus in the studied region. Muscle samples were obtained from 731 specimens belonging to 14 species and four families (Mustelidae, Ursidae, Felidae, and Canidae) in Primorsky Krai (Russia) in 2010-2020 and examined on Trichinella. The parasites were found in 124 specimens belonging to 11 species. The highest Trichinella prevalence was observed in Vulpes vulpes (64\%), Ursus arctos (57\%), and Lynx lynx (50\%). A relatively high ratio of infected animals (30-50\%) was found in Nyctereutes procyonoides, Ursus thibetanus, and Prionailurus bengalensis. The parasite prevalence was relatively low in the representatives of the Mustelidae family. Three species of the genus Trichinella (T. nativa, T. spiralis, and T. pseudospiralis) were found for carnivorans inhabiting the study area. Trichinella nativa was found the most frequently in natural ecosystems. Trichinella pseudospiralis was discovered for the first time both for $P$. bengalensis and for the area of the Primorsky Krai. The Carnivora ecology contributes to a high risk of infection by Trichinella species. The parasite prevalence was high in the species that combined different feeding habits, i.e. they acted as predators, scavengers and cannibals. A relatively long life expectancy also contributed to a higher risk of infection. A relatively high parasite prevalence of Trichinella in wild animals in the Primorsky Krai was caused by the high biological diversity of carnivorans. Our results are important for understanding the trichinosis circulation in natural communities and the possibility of human infestation. These data are also important for managing the carnivorans' populations in the Russian Far East. The issues of nature conservation in regard to the trichinosis circulation are also important for threatened animals, including Panthera tigris altaica.
\end{abstract}

Key words: animal ecology, nematode, parasite prevalence, parasites, predator, trichinosis

\section{Introduction}

Trichinosis is a widespread natural focal disease dangerous to humans (Campbell, 1983; Murrell, 2001; Pozio, 2005). In the wild, invasion circulates among carnivorans, primarily representatives of the order Carnivora (Britov, 1995; Skírnisson et al., 2010; Klun et al., 2019).

The features of Trichinella transfer from one host to another have been intensively studied in anthropogenic ecosystems (Beck, 1970; Gottstein et al., 2009; Pozio, 2014). But the range of hosts and the features of their transmission in natural ecosystems have generally not been studied yet.

In the Russian Far East, there were a few studies of Trichinella invasion of wild animals (Britov \& Sapunov, 1997; Gorodovich \& Gorodovich, 2009; Guba, 2009, 2010; Seryodkin, 2015b). These studies were mainly devoted to the description of the parasite prevalence in certain mammal species. In the Primorsky Krai, important studies on trichinosis were previously carried out by Britov (1995), who presented data on the infection of eleven species of wild carnivorans by this parasite. Britov (1995) reported on Trichinella infection in humans living in the Primorsky Krai, and listed the species composition of Trichinella. The diversity of Trichinella species and haplotypes and their distribution in carnivoran populations in the Primorsky Krai were partially addressed in Odoevskaya et al. (2018).

Until now, the features of the trichinosis circulation in the ecosystems of the Primorsky Krai, including Protected Areas (PAs), have not been adequately studied. In particular, the role of carnivorans in the parasite invasion circulation has not been assessed. In addition, the influence of the animal ecology on the Trichinella prevalence has not been evaluated. 
The study of the species composition and haplotype diversity of Trichinella circulating in natural ecosystems is of great interest for fundamental research as well (Mohandas et al., 2014).

The study aimed to identify the wild Carnivora species susceptible i) to Trichinella invasion, ii) to estimate the parasite prevalence (PP) for each mammal species, iii) to search for the dependence of the parasite prevalence in carnivorans on the ecology of the latter, iv) to assess the features of the trichinosis circulation in the local ecosystems, and v) to report on the species composition of Trichinella.

\section{Material and Methods \\ Study area}

Primorsky Krai is located in the south of the Russian Far East (Fig.). The Sikhote-Alin mountain system covers most of the area. It is a complex system of mountain ranges, river valleys, intermountain depressions, and mountain plateaus. By absolute altitude, the Sikhote-Alin mountain system belongs to the mid-altitude mountains. Part of the Primorsky Krai is represented by plains. The largest area of the region is occupied by the UssuriPrikhankaisk plain (Prikhankaisk lowland).
The study area is represented mainly by the natural forest complex. The most common forest formations are mixed broad-leaved and oak (Quercus mongolica Fisch. ex Ledeb.) forests of valleys and foothills, pine-broad-leaved forests of the lower and middle mountain zones, pine-spruce forests (Pinus koraiensis Siebold \& Zucc., Picea jezoensis (Siebold \& Zucc.) Carrière subsp. jezoensis) at an altitude of up to 800 $\mathrm{m}$ a.s.1., fir-spruce forests (Abies nephrolepis (Trautv.) Maxim., Picea jezoensis subsp. jezoensis) of the upper mountain zones, larch forests (Larix gmelinii (Rupr.) Kuzen. var. gmelinii) in swampy areas of river valleys, stony birch (Betula ermanii Cham. var. lanata Regel) forests of sub-goltsy altitudinal belt, and thickets of Pinus pumila (Pall.) Regel (Astafiev, 2006).

This area is characterised by a high diversity of species and natural communities due to the pronounced diversity of climatic, altitude and soil conditions, as well as its location at the junction of various biogeographic regions in Asia. The terrestrial mammal fauna of the Primorsky Krai includes more than 80 species, including 18 species of carnivorans (Pavlinov \& Lissovsky, 2012; Darman et al., 2019).

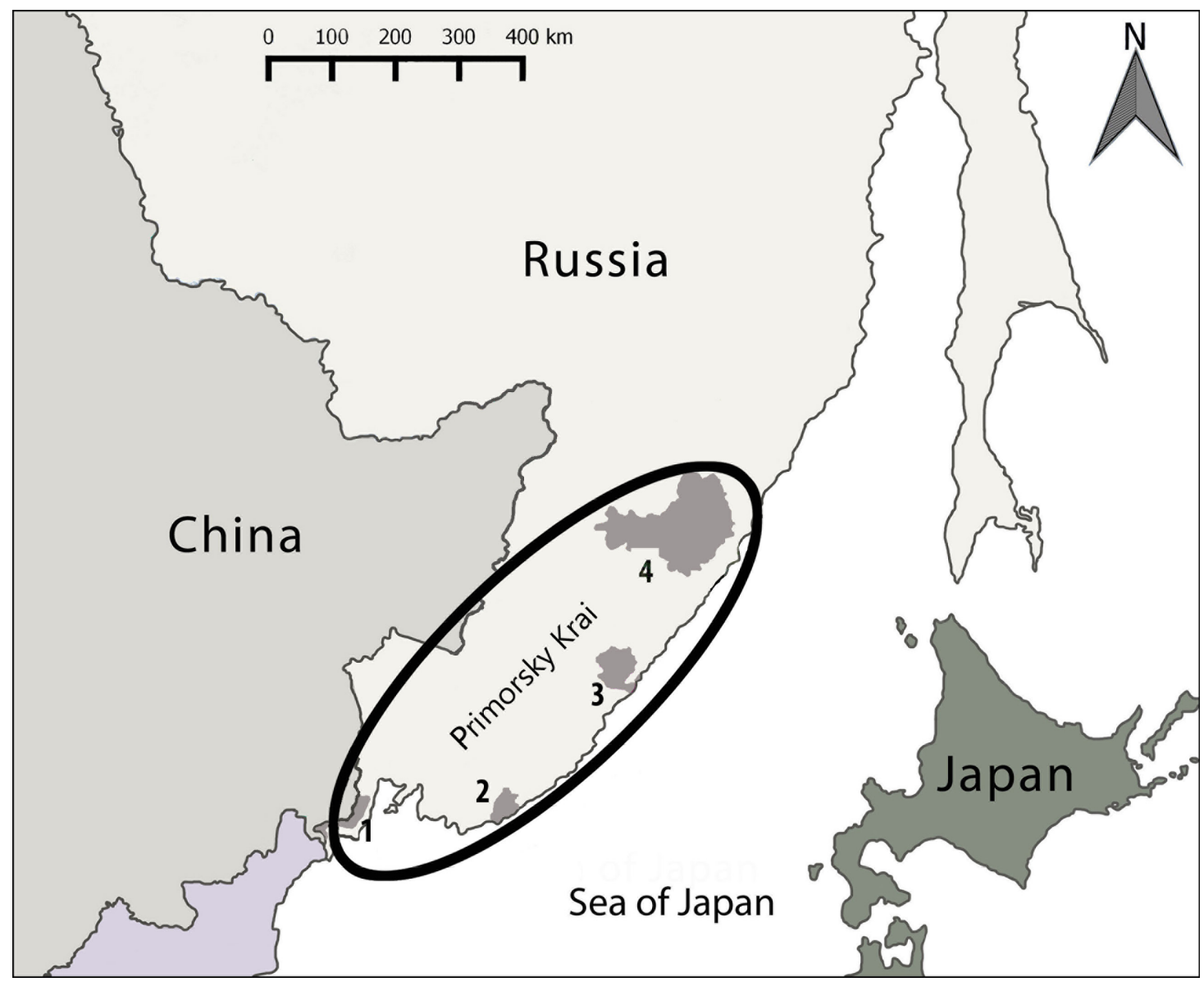

Fig. The study area of Trichinella invasion in wild Carnivora in the Primorsky Krai in 2010-2020. The federal-level Protected Areas are indicated in dark grey as: 1 - Land of the Leopard National Park, 2 - Lazovsky State Nature Reserve, 3 - SikhoteAlin State Nature Reserve, 4 - Bikin National Park. 


\section{Sampling}

In 2010-2020, muscle tissue was sampled from carnivorans killed by predators and hunters, as well as from animals which died from diseases and on the roads by traffic. The sampling was performed in most of the area of the Primorsky Krai, Russia (Fig.). The material was collected in a number of districts (Anuchinskiy, Chuguevskiy, Dalnerechenskiy, Khasanskiy, Khorolskiy, Kirovskiy, Krasnoarmeyskiy, Lazovskiy, Mikhailovskiy, Nadezhdinskiy, Partizanskiy, Pozharskiy, Shkotovskiy, Terneyskiy, and Yakovlevskiy) and in several municipalities (Artemovskiy, Bolshoy Kamen', Dalnegorskiy, Lesozavodskiy, Ussuriiskiy, and Vladivostokskiy) of the Primorsky Krai. The study area included single sites, buffer zones, and the surroundings of the following federal-level PAs: Sikhote-Alin State Nature Reserve, Lazovsky State Nature Reserve, Land of the Leopard National Park, and Bikin National Park (Fig.).

Muscle tissues were sampled and examined for 731 specimens of carnivorans belonging to four families, namely Mustelidae: Lutra lutra Linnaeus, 1758 (five individuals), Martes flavigula Boddaert, 1785 (three individuals), M. zibellina Linnaeus, 1758 (514 individuals), Meles leucurus Hodgson, 1847 (three individuals), Mustela sibirica Pallas, 1773 (22 individuals), and Neovison vison Schreber, 1777 (four individuals); Ursidae: Ursus arctos Linnaeus, 1758 (23 individuals), and U. thibetanus G. Cuvier, 1823 (16 individuals); Felidae: Lynx lynx Linnaeus, 1758 (10 individuals), Panthera tigris Linnaeus, 1758 (three individuals), and Prionailurus bengalensis Kerr, 1792 (72 individuals); Canidae: Canis lupus Linnaeus, 1758 (two individuals), Nyctereutes procyonoides Gray, 1834 (40 individuals), and Vulpes vulpes Linnaeus, 1758 (14 individuals).

\section{Trichinella larvae detection procedure}

In order to identify Trichinella larvae, fragments of striated muscle tissue of dead mammals (20-50 g) were studied using standard methods as follows: compression trichinoscopy and biochemical digestion in artificial gastric juice (AGJ), according to state methodology guidelines (MUK 4.2.2747-10, Russia). Each muscle tissue sample was initially examined using light microscopy (microscopes MBS9 and Zeiss AxioImager.Z1). Digital photography and subsequent processing of images was carried out in the Zeiss Axio Vision program.

\section{Estimation of the parasite prevalence}

The parasite prevalence of Trichinella was determined for the carnivorans. This number was not less than ten specimens. The parasite prevalence was calculated as the ratio of the number of infected animals to the total number of examined specimens of a certain species, expressed as a percentage. If the total number of specimens of a certain species was less than ten individuals, the possibility of their infection with Trichinella was assessed. Our data are accompanied by the data on the infection of carnivorans with Trichinella in the Primorsky Krai according to Britov (1995) (Table).

\section{Trichinella species identification}

Trichinella larvae were isolated from muscle tissues after peptolysis in AGJ. Then, they were repeatedly washed with water and physiological salt solution.

PCR was used for molecular genetic identification of Trichinella samples. Genomic DNA was obtained from 1-12 Trichinella larvae by digestion in proteinase $\mathrm{K}$ with mercaptoethanol (Holterman et al., 2006). Species identification was carried out by the nucleotide sequence of the mitochondrial genome site (CoxI gene and adjacent tRNA sequences). The sequence was obtained using primers $37 \mathrm{~F}$ Tri GCA GTAAAT TTA GAA TTT AAA C and 42R_Tri CCT AAT ATT CAT GGT GTT CAT A (Odoevskaya et al., 2018). After sequencing, the obtained data were compared with the analogous sequences of the representatives of Trichinella genus available in the NCBI GenBank. We analysed the obtained alignments using the methods of maximum parsimony, nearestneighbour algorithm, and maximum likelihood in the MEGA7 program (Kumar et al., 2016).

\section{Parasite prevalence}

Trichinella larvae were found in the muscles of 124 specimens (Table). The highest PP (> 50\%) was recorded for Vulpes vulpes and Ursus arctos. Relatively high Trichinella prevalence (> 30\%) was observed in Lynx lynx, Nyctereutes procyonoides, Prionailurus bengalensis, and Ursus thibetanus. In the Primorsky Krai, a low PP was found in two species of the Mustelidae family, Martes zibellina and Mustela sibirica. Trichinella infestation has also been reported for Canis lupus, Meles leucurus, and Neovison vison.

Compared to our data (Table), Britov (1995) reported a slightly lower PP for Vulpes vulpes and Ursus arctos and relatively higher values for $\mathrm{Ca}$ nis lupus, Panthera tigris, and Martes flavigula in terms of Trichinella invasion in the Primorsky Krai. In general, our study evidenced that Vulpes vulpes, Canis lupus, Nyctereutes procyonoides, 
Ursus arctos, U. thibetanus, Prionailurus bengalensis, Lynx lynx, and Panthera tigris are of the highest importance among the studied carnivorans for the circulation of Trichinella in the study area.

\section{Trichinella species composition}

The following three species of the genus Trichinella were found in the studied samples of carnivorans in the Primorsky Krai: T. nativa Britov \& Boev, 1972, T. spiralis (Owen, 1835), and T. pseudospiralis Garkavi, 1972. Trichinella nativa was observed in most of infected animals. This species was registered for Ursus arctos, U. thibetanus, Lynx lynx, Prionailurus bengalensis, Canis lupus, Vulpes vulpes, Nyctereutes procyonoides, Meles leucurus, Martes zibellina, and Mustela sibirica. Trichinella spiralis was found in two specimens of Martes zibellina, and Trichinella pseudospiralis in one specimen of Prionailurus bengalensis.

\section{Discussion}

\section{Parasite prevalence}

Similarly to the Primorsky Krai, a relatively high Trichinella prevalence in Vulpes vulpes is also observed in the Amur region (Russia), accounting for $43.2 \%$ (Gorodovich \& Gorodovich, 2009), and in Belarus, for $35.3 \%$ (Penkevich \& Anisimova, 2013). In some regions of Russia, PP in $V$. vulpes is lower, i.e. $22.3 \%$ in the Kursk region (Vagin \& Malysheva, 2010), 15\% in the central part of Russia (Andreyanov, 2014), 12.2\% in Kamchatka (Britov \& Sapunov, 1997), 7.5\% in the Altaisky
Krai (Malkina \& Konyaev, 2013), and 3.3\% in the Republic of Yakutia (Odnokurtsev et al., 2015).

Trichinella prevalence in Canis lupus varies in different parts of the wide range of this predator. Thus, PP comprises $15.2 \%$ and higher in the Republic of Yakutia (Odnokurtsev et al., 2015), 19.7\% in the Altaisky Krai (Malkina \& Konyaev, 2013), $14.3 \%$ in Kamchatka (Britov \& Sapunov, 1997), and $11 \%$ in the central part of Russia (Andreyanov, 2014). In C. lupus, PP reaches $22 \%$ in the southern regions of the Russian Far East, and up to 50\% in the northern regions (Yudin, 1992). High values of PP were noted in Estonia (up to 50\%) (Moks et al., 2006), and Latvia (69.7\%) (Bagrade et al., 2009).

Nyctereutes procyonoides is characterised by relatively high PP in Belarus (42.8\%) (Penkevich \& Anisimova, 2013), and in the Amur region (33.3\%) (Gorodovich \& Gorodovich, 2009). These results are comparable to that observed in the Primorsky Krai. Much lower values were reported in the central part of Russia, 12\% (Andreyanov, 2014).

Trichinella prevalence in Ursus arctos varies in different regions of the Russian Far East. In particular, PP is the lowest in the Sakhalin region $(2.4 \%)$, but reaches up to $30.6 \%$ in Kamchatka and even up to $61 \%$ in the Magadan region (Seryodkin, 2015b). In the Sikhote-Alin mountain range (including Primorsky Krai), it ranges from $45 \%$ to $70 \%$ (Yudin, 1991). In other Russian regions, $P P$ also varies in $U$. arctos as follows: $13.3 \%$ in Altaisky Krai (Malkina \& Konyaev, 2013), and $19.7 \%$, in the Republic of Yakutia (Odnokurtsev et al., 2015).

Table. Parasite prevalence of Trichinella spp. in wild carnivorans inhabiting the Primorsky Krai, Russia

\begin{tabular}{|c|c|c|c|c|c|c|}
\hline \multirow[b]{2}{*}{ Host species } & \multicolumn{3}{|c|}{ Original data } & \multicolumn{3}{|c|}{ According to Britov (1995) } \\
\hline & \begin{tabular}{|c|}
$\begin{array}{c}\text { Number of studied } \\
\text { specimens }\end{array}$ \\
\end{tabular} & \begin{tabular}{|c|}
$\begin{array}{c}\text { Number of infected } \\
\text { specimens }\end{array}$ \\
\end{tabular} & $\mathrm{PP}, \%$ & $\begin{array}{c}\text { Number of studied } \\
\text { specimens }\end{array}$ & $\begin{array}{c}\text { Number of infected } \\
\text { specimens }\end{array}$ & $\mathrm{PP}, \%$ \\
\hline Vulpes vulpes & 14 & 9 & 64.29 & 71 & 15 & 21.13 \\
\hline Canis lupus & 2 & 1 & scarce data & 33 & 15 & 45.45 \\
\hline Nyctereutes procyonoides & 40 & 17 & 42.50 & 78 & 28 & 35.90 \\
\hline Ursus arctos & 23 & 13 & 56.52 & 211 & 58 & 27.49 \\
\hline Ursus thibetanus & 16 & 6 & 37.50 & - & - & - \\
\hline Prionailurus bengalensis & 72 & 25 & 34.72 & 26 & 8 & 30.77 \\
\hline Lynx lynx & 10 & 5 & 50.00 & 8 & 4 & scarce data \\
\hline Panthera tigris & 3 & 0 & scarce data & 15 & 8 & 53.33 \\
\hline Meles leucurus & 3 & 1 & scarce data & 33 & 9 & 27.27 \\
\hline Martes zibellina & 514 & 42 & 8.17 & - & - & - \\
\hline Martes flavigula & 3 & 0 & scarce data & 11 & 8 & 72.73 \\
\hline Mustela sibirica & 22 & 4 & 18.18 & 40 & 1 & 2.50 \\
\hline Neovison vison & 4 & 1 & scarce data & - & - & scarce data \\
\hline Lutra lutra & 5 & 0 & scarce data & 1 & 0 & scarce data \\
\hline
\end{tabular}


Comparing to our data, a lower Trichinella prevalence $(5.9 \%)$ was reported for Ursus thibetanus in the Russian Far East (Britov \& Sapunov, 1997). This evidences that PP may change over time and may vary in different areas of the same region.

Our data on the PP in Prionailurus bengalensis in comparison to Britov (1995), obtained earlier in the Primorsky Krai, were comparable (34.7\% and $30.8 \%$, respectively). A serological study indicated a presence of antibodies to Trichinella in $10 \%$ of $P$. bengalensis animals in the south of Primorsky Krai (Naidenko et al., 2019).

In the Primorsky Krai, the PP in Lynx lynx is higher than in the Amur region, another region of the Russian Far East, where Trichinella PP accounts for $21.1 \%$ (Guba, 2010). However, in other parts of L. lynx range, the PP is higher. Its values are 50\% in Estonia (Malakauskas et al., 2007), up to $70 \%$ in Finland (Airas et al., 2010), and $88.9 \%$ in Latvia (Malakauskas et al., 2007).

Despite not having found Trichinella in Panthera tigris, caused by a small sampling, the PP was apparently quite high in these carnivorans in the Russian Far East. Trichinella infection was reported in $53.3 \%$ of studied specimens (Britov, 1995). In the Amur region, all examined P. tigris (four individuals) were infected (Gorodovich \& Gorodovich, 2009). In the south of the Primorsky Krai, a serological study reported on the antibodies to Trichinella in $72 \%$ of P. tigris individuals (Naidenko et al., 2019).

In Meles leucurus, Trichinella prevalence ranged as $13.2-17.4 \%$ in the Amur region (Gorodovich \& Gorodovich, 2009; Solovieva et al., 2017), and 6.7\% in the Altaisky Krai (Malkina \& Konyaev, 2013). These values are lower than we observed in the Primorsky Krai. In the closely related species Meles meles Linnaeus, 1758, inhabiting Europe, the prevalence of this parasite also varied in different regions, for example, from $6.2 \%$ in the Balkans (Klun et al., 2019 ) and up to $25 \%$ in the central part of Russia (Andreyanov, 2014).

In Martes flavigula, the high PP compared to other Mustelidae species in the study area may be caused by the small sampling size. Other Mustelidae species are characterised by lower Trichinella prevalence than observed for M. flavigula in Primorsky Krai as well as in other Russian regions. For example, for Martes zibellina, it was $1.9 \%$ in Kamchatka (Britov \& Sapunov, 1997), $2.2 \%$ in the Amur region (Gorodovich
\& Gorodovich, 2009), and 4.3\% in the Altaisky Krai (Malkina \& Konyaev, 2013). In Mustela sibirica, PP varied from $5.2 \%$ to $11.1 \%$ in the Amur region (Gorodovich \& Gorodovich, 2009; Guba, 2009; Solovieva et al., 2017). Neovison vison was characterised by PP of $1.1 \%$ in the Amur region (Gorodovich \& Gorodovich, 2009), 3\% in the northern part of the Russian Non-Chernozem Zone (Maslennikova \& Strelnikov, 2017), while it comprised $16.6 \%$ in the Altaisky Krai (Malkina \& Konyaev, 2013). The only exceptions were relatively high PP in the Republic of Yakutia (24.9\%) for Martes zibellina (Kokolova, 2014), and in the Kursk region (36.6\%) for Neovison vison (Vagin \& Malysheva, 2010). Despite not having found Trichinella in Lutra lutra, Britov \& Sapunov (1997) indicated that 3\% of population of this species was infected by Trichinella in the Russian Far East.

In general, Trichinella prevalence in the carnivorans is predictably higher than in other taxonomic groups, including omnivores, due to their ecological peculiarities. In Sus scrofa Linnaeus, 1758 , PP was $0.65 \%$ in the Russian Far East (Britov, 1995). It reaches up to $2.2 \%$ in the Amur region (Solovieva et al., 2017). It is known that rodents (Rodentia) and insectivores (Eulipotyphla) have low values of Trichinella prevalence in all the regions studied so far (e.g. Pozio, 2005; Malkina \& Konyaev, 2013; Penkevich \& Anisimova, 2013; Andreyanov, 2014).

\section{The influence of animal ecology on Trichi- nella prevalence}

In nature, the most carnivorans (e.g. Panthera tigris, Lynx lynx, Prionailurus bengalensis, Canis lupus, and Vulpes vulpes) with high PP values are characterised by a long life expectancy, that may exceed ten years (Tumanov, 2003; Yudin \& Yudina, 2009; Yudin, 2015), while it may exceed up to 20 years or even more in $U r$ sus arctos and $U$. thibetanus (Tumanov, 2003; Seryodkin et al., 2017). Undoubtedly, a longer life span increases the chances of a carnivoran to eat an animal infected with Trichinella.

The prey spectra of large carnivorans include smaller carnivorans. In addition, cannibalism is a characteristic of such species as Ursus arctos, $U$. thibetanus, Vulpes vulpes, and Prionailurus bengalensis (Yudin, 1986; Seryodkin et al., 2012; Seryodkin, 2015a; Seryodkin \& Burkovskiy, 2019). In the Primorsky Krai, the diet of all large carnivorans includes Sus 
scrofa, which is also susceptible to Trichinella infection (Britov, 1995).

In addition to predation, some species with a relatively high degree of Trichinella infection are also characterised by necrophagy. Therefore, they are also able to eat any mammal species potentially carrying Trichinella larvae. Ursus arctos and $U$. thibetanus are potential scavengers (Seryodkin, 2015a), as well as Vulpes vulpes (Yudin, 1986), Nyctereutes procyonoides (Krivosheev, 1984), and Prionailurus bengalensis (Yudin, 2015).

Ursus thibetanus and especially $U$. arctos have high risks to be infected by Trichinella. As they are characterised by the highest life expectancy among all the carnivorans in the study area, they consume animal corpses more often than any other species. In addition, they are characterised by both cannibalism and predation. Ursus arctos feeds on all mammalian species, including U. thibetanus, Panthera tigris, Nyctereutes procyonoides, and Meles leucurus. Moreover, the occurrence of mammal remains in the scats in $U$. arctos is 4.3 times higher than that in $U$. thibetanus and amounts to $18.4 \%$ and $4.3 \%$, respectively (Seryodkin, 2015a). Ursus arctos is able to hunt actively. But Ursus thibetanus may be characterised by a lower degree of predation. Thus, the lower infection of $U$. thibetanus by Trichinella compared with $U$. arctos is explained by the peculiarities of their feeding behaviour.

Panthera tigris, Lynx lynx, and Canis lupus are specialised predators, which hunt mainly on ungulates. However, they are able to catch several mammals infected with Trichinella. Ursus thibetanus, Meles leucurus, Nyctereutes procyonoides, Vulpes vulpes, Canis lupus familiaris Linnaeus, 1758 and others are in the list of their prey (Yudin, 1992; Matyushkin et al., 2003; Kerley et al., 2015; Seryodkin, 2015a). In the wild, Panthera tigris' lifespan may reach 19 years (Yudin \& Yudina, 2009). It is known that Canis lupus may live up to 17 years (Tumanov, 2003).

Seven-year-old to eight-year-old Vulpes vulpes are usually found in natural habitats. Nevertheless, it is known that they may live up to 11 years (Tumanov, 2003). Despite small rodents and birds being the basis of the Vulpes vulpes diet in the Far East they eat any animal food (Krivosheev, 1984). It was reported that $V$. vulpes ate domestic dogs, while Nyctereutes procyonoides, Mustela sibirica may hunt on representatives of their own species (Yudin, 1986). Such diet contributes to Trichinella infection of Vulpes vulpes. Dead animals are also a part of the Nyctereutes procyonoides diet (Krivosheev, 1984), similarly as it is observed for Vulpes vulpes.

Small rodents, birds, and, to a lesser extent, other animals, are of the highest importance in Prionailurus bengalensis' diet (Yudin, 2015). The diet of this species includes insectivores, Vulpes vulpes, Nyctereutes procyonoides, and individuals of the same species (Seryodkin \& Burkovskiy, 2019). Together with necrophagy, this promotes Trichinella infection. Prionailurus bengalensis lives up to 12-14 years in nature (Yudin, 2015).

Meles leucurus is an omnivore animal. Small animals, fruits, and sappy rhizomes of plants form the basis of its diet. Besides, insects form a considerable proportion in its diet. $\mathrm{Me}$ les leucurus feeds on frogs and small rodents. It destroys bird nests and consumes dead animals (Krivosheev, 1984). In nature, the maximal life expectancy of this species does not exceed 12 15 years (Tumanov, 2003). Thus, M. leucurus is also susceptible to Trichinella infection, but to a lesser extent than species of Ursidae, Canidae, and Felidae.

The relatively low Trichinella prevalence in Martes zibellina and Mustela sibirica is explained by the predominance of small rodents, birds, and amphibians in their diet (Krivosheev, 1984), as well as by a short life span (Tumanov, 2003). In the Primorsky Krai, PP in small rodents, the main prey of the mentioned animal species, is small and amounts to $0.65 \%$ (Britov, 1995).

Mustelidae species leading a semi-aquatic lifestyle (Lutra lutra and Neovison vison) have the lowest chance of Trichinella infection. The food spectra of these species include primarily fish, amphibians, various other aquatic animals, rodents, and birds (Krivosheev, 1984). Life expectancy of L. lutra and $N$. vison often does not exceed six years in the wild (Tumanov, 2003).

\section{Trichinella species composition}

In general, Trichinella nativa is the most common Trichinella species in the Russian Far East, and in the Primorsky Krai, in particular. This nematode usually parasitises in wild carnivorans. And it is distributed over the wide area of the temperate, subarctic and arctic zones in the Eurasia and North America (Gottstein et al., 2009).

Trichinella spiralis is the most widespread Trichinella species, because it is adapted to syn- 
anthropic animals, including Sus scrofa domesticus Erxleben, 1777 and Rattus spp. (Gottstein et al., 2009). The wide distribution of this Trichinella species is the result of the anthropogenic dissemination of this invasion along with Sus s. domesticus (Rosenthal et al., 2008). However, the infection of sables by the larvae of T. spiralis is possible since this parasite has been found in these Mustelidae species in the present study.

In our study, T. pseudospiralis was found for the first time in the Primorsky Krai, as well as for Prionailurus bengalensis as a host. Earlier, in the Russian Far East, this Trichinella species was recorded among wild animals in Vulpes vulpes, Nyctereutes procyonoides, and Sus scrofa in the Amur region (Gorodovich \& Gorodovich, 2009). Trichinella pseudospiralis is often recorded in birds (Pozio, 2005; Garkavi, 2007). Since in the Primorsky Krai birds are one of the main food sources of P. bengalensis (Yudin, 2015; Seryodkin \& Burkovskiy, 2019), infection may occur when they are eaten. In addition, small rodents and insectivores (Garkavi, 2007), also consumed by $P$. bengalensis, being the links for spreading of T. pseudospiralis in the study area.

\section{Trichinosis circulation in ecosystems}

Nowadays, there is a generally accepted concept that divides the foci of trichinosis invasion into synanthropic (Trichinella circulates mainly between Rattus spp. and Sus scrofa domesticus) and natural (circulation occurs between wild animals). However, over the past few decades, an analysis of the epidemic and epizootic conditions indicates an increasingly important role of wild animals in the transmission of invasion to people and domestic animals, including PAs (Britov, 1995; Britov \& Nivin, 2009; Solovieva et al., 2017). Generally, trichinosis has a natural focal character both in the Primorsky Krai and in the Russian Far East (Britov, 1995; Britov \& Sapunov, 1997).

The area of Primorsky Krai, including PAs, is characterised by a high biodiversity level, including carnivorans represented by predators and scavengers. This determines the widespread occurrence of trichinosis, which is relatively large compared with PP in the wild animals in other regions. Carnivora species play the largest role in the trichinosis circulation in the forest ecosystems prevailing in the Primorsky Krai. Vulpes vulpes, Canis lupus, Nyctereutes procyonoides, Ursus arctos, U. thibetanus, Prionailurus bengalensis, Lynx lynx, and Panthera tigris are the most considerable hosts of Trichinella. Their predation on other carnivorans widely known in literature, as well as cannibalism, play an important role in the Trichinella circulation. Other mammals, which are able to consume animals, such as Sus scrofa and small rodents, are involved in the spread of this invasion to a lesser extent.

Predatory birds are of high importance in the dispersion of Trichinella larvae. Birds are active destructors of organic waste in natural ecosystems, including dead animals (Odoyevskaya, 2010; Bukina, 2013). Previous studies showed that alimentary contact of predatory birds with Trichinella has developed historically. It plays a considerable role in the epizootology of trichinosis (Garkavi, 2007; Odoyevskaya, 2010). Only $T$. pseudospiralis parasitises and completely passes all ontogenesis stages in the muscle tissues of birds. Larvae of capsule-forming Trichinella species (T. nativa and T. spiralis), passing through the digestive tract of birds, can also enter both invertebrate animals (Insecta, Mollusca, Crustacea) and herbivorous and omnivorous mammals (Odoevskaya, 2011; Krapivin \& Odoyevskaya, 2019).

Necrophagous insects can be mechanical vectors of Trichinella larvae (Andreyanov, 2014; Riva et al., 2015). The fundamental possibility for mammal infection with Trichinella by eating crustaceans, which consumed infected meat for the last $24 \mathrm{~h}$., was experimentally confirmed (Krapivin \& Odoevskaya, 2019).

\section{Conclusions}

In the Primorsky Krai, the highest PP of Trichinella larvae is observed in mammals (both predators and scavengers) having a relatively long lifespan. The PP of particular species is preconditioned both by the host diet and a set of preferred prey species. That is why large carnivorans and species characterised by cannibalism were the most infected compared to other animals.

In the Primorsky Krai, carnivorans have relatively high Trichinella prevalence compared to other regions. This is ensured by the high biodiversity in the study area, including a large number of carnivorans. Carnivorans, mostly species of the Canidae, Ursidae, and Felidae, play a leading role in the Trichinella circulation in ecosystems. Its PP in some species of these orders reaches $64 \%, 57 \%$, and $50 \%$, respectively. In fact, natural trichinosis is widely distributed. The Trichinella infestation is promoted not only 
by mammals, but also by birds and mechanical hosts (i.e. invertebrates).

Three Trichinella species (T. nativa, T. spiralis, and $T$. pseudospiralis) circulate in the natural ecosystems of the Russian Far East, including PAs. Carnivorans are infected mostly by Trichinella nativa.

\section{References}

Airas N., Saari S., Mikkonen T., Virtala A.M., Pellikka J., Oksanen A., Isomursu M., Kilpelä S.S., Lim C.W., Sukura A. 2010. Sylvatic Trichinella spp. infection in Finland. Journal of Parasitology 96(1): 67-76. DOI: 10.1645/GE-2202.1

Andreyanov O.N. 2014. Characterization of natural foci of trichinosis infection. Current issues of the humanities and natural sciences 4(2): 232-235. [In Russian]

Astafiev A.A. (Ed.). 2006. Plant and animal life of the Sikhote-Alin State Nature Reserve. Vladivostok: Primpoligrafkombinat. 436 p. [In Russian]

Bagrade G., Kirjušina M., Vismanis K., Ozoliņš J. 2009. Helminth parasites of the wolf Canis lupus from Latvia. Journal of Helminthology 83(1): 63-68. DOI: 10.1017/ S0022149X08123860

Beck J.W. 1970. Trichinosis in domesticated and experimental animals. In: S.E. Gould (Ed.): Trichinosis in man and animals. Springfield: C.C. Thomas Publisher. P. 61-80.

Britov V.A. 1995. The trichinosis problem in Primorsky Krai. Vladivostok: Primorsky Branch of the Far East Zonal Scientific Research Veterinary Institute. 51 p. [In Russian]

Britov V.A., Nivin E.A. 2009. To the role of Trichinella in biocoenoses. Theory and practice of animal parasitic diseases 10: 78-80. [In Russian]

Britov V.A., Sapunov V.P. 1997. The problem of trichinosis in Kamchatka. Vladivostok; Petropavlovsk-Kamchatsky: Primorsky Branch of the Far East Zonal Scientific Research Veterinary Institute. 57 p. [In Russian]

Bukina L.A. 2013. The role of birds in the spread of Trichinella on seashores of the Chukchi Peninsula. Veterinary of Farm Livestock 2: 38-42. [In Russian]

Campbell W.C. 1983. Epidemiology I modes of transmission. In: W.C. Campbell (Ed.): Trichinella and Trichinosis. New York, London: Plenum Press. P. 425-444.

Darman Yu.A., Storozhuk V.B., Sedash G.A. 2019. Hydropotes inermis (Cervidae), a new species for the Russian fauna registered in the Land of Leopard National Park (Russia). Nature Conservation Research 4(3): 127-129. DOI: 10.24189/ncr.2019.057 [In Russian]

Garkavi B.L. 2007. Trichinellosis caused by Trichinella pseudospiralis (morphology and biology, epizootology and epidemiology, diagnostics, control measures and preventive maintenance). Russian Journal of Parasitology 2: 35-116. [In Russian]
Gorodovich N.M., Gorodovich S.N. 2009. Monitoring of trichinosis in the Russian Far East. Theory and practice of animal parasitic diseases 10: 129-131. [In Russian]

Gottstein B., Pozio E., Nockler K. 2009. Epidemiology, diagnosis, treatment, and control of trichinellosis. Clinical Microbiology Reviews 22(1): 127-145. DOI: 10.1128/ CMR.00026-08

Guba L.A. 2009. Detection of trichinosis in the Siberian weasel (Mustela sibirica) in the Amur region of the Far East. Theory and practice of animal parasitic diseases 10: 141-142. [In Russian]

Guba L.A. 2010. Detection of trichinosis in the lynx (Felis lynx) in the Amur region of the Far East. Theory and practice of animal parasitic diseases 11: 136-138. [In Russian]

Holterman M., van der WurffA., van den Elsen S., van Megen H., Bongers T., Holovachov O., Bakker J., Helder J. 2006. Phylum-wide analysis of SSU rDNA reveals deep phylogenetic relationships among nematodes and accelerated evolution towards crown clades. Molecular Biology and Evolution 23(9): 1792-1800. DOI: 10.1093/molbev/msl044

Kerley L.L., Mukhacheva A.S., Matyukhina D.S., Salmanova E., Salkina G.P., Miquelle D.G. 2015. A comparison of food habits and prey preference of Amur tiger (Panthera tigris altaica) at three sites in the Russian Far East. Integrative Zoology 10(4): 354-364. DOI: 10.1111/1749-4877.12135

Klun I., Ćosić N., Ćirović D., Vasilev D., Teodorović V., Djurković-Djaković O. 2019. Trichinella spp. in wild mesocarnivores in an endemic setting. Acta Veterinaria Hungarica 67(1): 34-39. DOI: 10.1556/004.2019.004

Kokolova L.M. 2014. Trichinosis in animals of Yakutia. Theory and practice of animal parasitic diseases 15: 110-113. [In Russian]

Krapivin V.A., Odoevskaya I.M. 2019. Some crustacean species as transport hosts for Trichinella nativa in the White Sea. Annals of Parasitology 65(1): 215-216.

Krivosheev V.G. (Ed.). 1984. Terrestrial mammals of the Far East of the USSR: Identificator. Moscow: Nauka. 358 p. [In Russian]

Kumar S., Stecher G., Tamura K. 2016. MEGA7: Molecular evolutionary genetics analysis version 7.0 for bigger datasets. Molecular Biology and Evolution 33(7): 1870-1874. DOI: 10.1093/molbev/msw054

Malakauskas A., Paulauskas V., Järvis T., Keidans P., Eddi C., Kapel C.M.O. 2007. Molecular epidemiology of Trichinella spp. in three Baltic countries: Lithuania, Latvia, and Estonia. Parasitology Research 100(4): 687-693. DOI: 10.1007/s00436-006-0320-y

Malkina A.V., Konyaev S.V. 2013. Morphological and molecular genetic characteristics of Trichinella in the Altaisky Krai. Theory and practice of animal parasitic diseases 14: 205-210. [In Russian]

Maslennikova O.V., Strelnikov D.P. 2017. Trichinosis of the American mink in the north of the Non-Chernozem Zone. Theory and practice of animal parasitic diseases 18: 259-261. [In Russian] 
Matyushkin E.N., Podol'siy S.A., Tkachenko K.N. 2003. The South of Far East. In: E.N. Matyushkin, M.A. Vaisfeld (Eds.): The lynx. Regional features of ecology, use and protection. Moscow: Nauka. P. 423-472.

Mohandas N., Pozio E., La Rosa G., Korhonen P.K., Young N.D., Koehler A.V., Hall R.S., Sternberg P.W., Boag P.R., Jex A.R., Chang B., Gasser R.B. 2014. Mitochondrial genomes of Trichinella species and genotypes - a basis for diagnosis, and systematic and epidemiological explorations. International Journal for Parasitology 44(14): 1073-1080. DOI: 10.1016 /j.ijpara.2014.08.010

Moks E., Jõgisalu I., Saarma U., Talvik H., Järvis T., Valdmann H. 2006. Helminthologic survey of the wolf (Canis lupus) in Estonia, with an emphasis on Echinococcus granulosus. Journal of Wildlife Diseases 42(2): 359 365. DOI: 10.7589/0090-3558-42.2.359

Murrell K.D. 2001. Trichinellosis: now and forevermore? Parasite 8: 11-13. DOI: 10.1051/parasite/200108s2011

Naidenko S.V., Hernandez-Blanco J.A., Erofeeva M.N., Litvinov M.N., Rozhnov V.V. 2019. Serum prevalence to non-viral pathogens in wild felids of Southern Primorye, Russia. Nature Conservation Research 4(1): 99105. DOI: $10.24189 /$ ncr.2019.010

Odnokurtsev V.A., Sedalishchev V.T., Okhlopkov I.M., Nikolaev E.A., Mamaev N.V. 2015. Dissemination of trichinellosis (Trichinella Railliet, 1895) in preying mammals within Yakutia area. Russian Journal of Parasitology 2: 43-48. [In Russian]

Odoyevskaya I.M. 2010. The role of birds in the epizootology of trichinosis in arctic marine mammals. Medical parasitology and parasitic diseases 3: 32-37. [In Russian]

Odoyevskaya I.M. 2011. Significance of birds in the dissemination of Trichinella spp. larvae in coastal and aquatic biocenoses. Medical parasitology and parasitic diseases 1: 12-16. [In Russian]

Odoevskaya I.M., Seryodkin I.V., Spiridonov S.E. 2018. The diversity of Trichinella in natural habitats of the Russian Far East. Russian Journal of Nematology 26(2): 123-128. DOI: 10.24411/0869-6918-2018-100012

Pavlinov I.Ya., Lissovsky A.A. (Eds.). 2012. The mammals of Russia: A taxonomic and geographic reference. Moscow: KMK Scientific Press Ltd. 604 p. [In Russian]

Penkevich V.A., Anisimova E.I. 2013. Trichinellesis of the wild mammals in Polesskij State Radio-Ecological Reserve. Proceedings of the National Academy of Sciences of Belarus 3: 101-104.

Pozio E. 2005. The broad spectrum of Trichinella hosts: from cold- to warm-blooded animals. Veterinary Parasitology 132(1-2): 3-11. DOI: 10.1016/j.vetpar.2005.05.024

Pozio E. 2014. Searching for Trichinella: not all pigs are created equal. Trends in Parasitology 30(1): 4-11. DOI: 10.1016/j.pt.2013.11.001

Riva E., Fiel C., Steffan P. 2015. The immature stages of Dermestes maculatus, Sarcophaga sp. and Phaenicia sericata as potential paratenic hosts for Trichinella spi- ralis in nature. Parasitology Research 114(1): 149-154. DOI: $10.1007 /$ s00436-014-4171-7

Rosenthal B.M., LaRosa G., Zarlenga D., Dunams D., Yao C., Liu M., Pozio E. 2008 Human dispersal of Trichinella spiralis in domesticated pigs. Infection, Genetics and Evolution 8(6): 799-805. DOI: 10.1016/j. meegid.2008.07.008

Seryodkin I.V. 2015a. Diet composition of brown bear and Asiatic black bear in the Middle Sikhote-Alin (Russian Far East): comparative study. The Bulletin of Irkutsk State University. Series Biology. Ecology 14: 32-38. [In Russian]

Seryodkin I.V. 2015b. Trichinosis of brown bear and Asiatic black bear in the Russian Far East. Bulletin of Kras GAU 12: 167-173. [In Russian]

Seryodkin I.V., Burkovskiy O.A. 2019. Food habit analysis of the Amur leopard cat Prionailurus bengalensis euptilurus in the Russian Far East. Biology Bulletin 46(6): 648-653. DOI: 10.1134/S1062359019660038

Seryodkin I.V., Paczkowski J., Leacock W.B., Zhakov V.V., Nikanorov A.P., Lisitsyn D.V. 2017. Main morphometric characteristics of brown bears in Kamchatka and Sakhalin. Bulletin of Kamchatka State Technical University 41: 83-92. DOI: 10.17217/2079-0333-2017-4183-92 [In Russian]

Seryodkin I.V., Zaitsev V.A., Goodrich J.M., Miquelle D.G., Petrunenko Y.K. 2012. Type of preys and wild boar (Sus scrofa) significance in Amur tiger's (Panthera tigris altaica) diet in the Middle Sikhote-Alin. Achievements in the Life Sciences 5: 77-93.

Skírnisson K., Marucci G., Pozio E. 2010. Trichinella nativa in Iceland: An example of Trichinella dispersion in a frigid zone. Journal of Helminthology 84(2): 182-185. DOI: 10.1017/S0022149X09990514

Solovieva I.A., Bondarenko G.A., Trukhina L.I., Ivanov D.A. 2017. Spreading of Trichinella infection causative agent among wild animals in the Amur region. Theory and practice of parasitic disease control 18: 467-469. [In Russian]

Tumanov I.L. 2003. Biological characteristics of carnivores mammals of Russia. Saint-Petersburg: Nauka. 448 p. [In Russian]

Vagin N.A., Malysheva N.S. 2010. Trichinosis in natural and synanthropic biocenoses of the Kursk region. Russian Journal of Parasitology 2: 33-36. [In Russian]

Yudin V.G. 1986. The fox of the Far East of the USSR. Vladivostok: Far Eastern Scientific Center of AS USSR. 284 p. [In Russian]

Yudin V.G. 1991. Aggressive behaviour in brown and Himalayan black bears in Primorye. In: Bears of the USSR - state of populations. Rzhev: Rzhev Printing House. P. 253-259. [In Russian]

Yudin V.G. 1992. The wolf of the Russian Far East. Blagoveshchensk: Far-Eastern Branch of RAS. 312 p. [In Russian]

Yudin V.G. 2015. Far-Eastern wild cat. Vladivostok: Dalnauka. 443 p. [In Russian]

Yudin V.G., Yudina E.V. 2009. The tiger of the Far East of Russia. Vladivostok: Dalnauka. 485 p. [In Russian] 


\title{
ЗАРАЖЕННОСТЬ ТРИХИНЕЛЛАМИ ДИКИХ ХИЩНЫХ МЛЕКОПИТАЮЩИХ В ПРИМОРСКОМ КРАЕ, ДАЛЬНИЙ ВОСТОК РОССИИ
}

\author{
И. В. Середкин ${ }^{1}$, И. М. Одоевская ${ }^{2}$, С. В. Коняев ${ }^{3}$, С. Э. Спиридонов ${ }^{4}$ \\ ${ }^{1}$ Тихоокеанский институт географии ДВО РАН, Россия \\ *e-mail: seryodkinivan@inbox.ru \\ ${ }^{2}$ Всероссийский научно-исследовательский институт экспериментальной \\ ветеринарии имени К.И. Скрябина и Я.Р. Коваленко РАН, Россия \\ ${ }^{3}$ Институт систематики и экологии животных СО РАН, Россия \\ ${ }^{4}$ Институт проблем экологии и эволюичии имени А.Н. Северияова РАН, Россия
}

\begin{abstract}
Нематоды рода Trichinella являются возбудителями трихинеллеза - зоонозной инвазии, заражающей человека, диких и домашних животных. На Дальнем Востоке трихинеллез имеет природно-очаговый характер, а резервуарами трихинелл являются в основном хищные млекопитающие (Carnivora), обитающие в природных биоценозах, в том числе на особо охраняемых природных территориях. Особенности циркуляции трихинелл в естественной среде, доля зараженных диких животных разных видов и видовой состав трихинелл в регионе остаются недостаточно изученным. В 2010-2020 гг. в Приморском крае на наличие трихинелл обследованы пробы мышц от 731 экземпляра хищных млекопитающих 14 видов из четырех семейств (Mustelidae, Ursidae, Felidae, Canidae). Положительными были пробы от 124 млекопитающих 11 видов. Наибольшая экстенсивность инвазии трихинеллами была у Vulpes vulpes (64\%), Ursus arctos (57\%) и Lynx lynx (50\%). Относительно высокая доля зараженных животных (30-50\%) была у Nyctereutes procyonoides, Ursus thibetanus и Prionailurus bengalensis. У представителей семейства Mustelidae зараженность была относительно низкой. У хищных млекопитающих на территории исследования обнаружено три вида рода Trichinella: T. nativa, T. spiralis и T. pseudospiralis. При этом наибольшее распространение в природных биоценозах имеет T. nativa. У P. bengalensis, а также на территории Приморского края впервые обнаружена T. pseudospiralis. Экология хищных млекопитающих обуславливает вероятность их заражения. Высокую экстенсивность инвазии имеют животные, для которых характерны одновременно хищничество, падальничество и каннибализм и при этом имеющие относительно большую продолжительность жизни. Относительно высокие показатели зараженности диких животных трихинеллами в Приморском крае обусловлены высоким биологическим разнообразием плотоядных животных. Полученные результаты важны для понимания особенностей циркуляции трихинеллеза в естественных биоценозах и возможности заражения человека, а также имеют ценность для управления популяциями хищных млекопитающих на Дальнем Востоке России. Природоохранный аспект имеет участие в циркуляции трихинеллеза редких и охраняемых видов животных, включая Panthera tigris altaica.
\end{abstract}

Ключевые слова: нематода, трихинеллез, хищник, экология животных, экстенсивность инвазии 